\title{
СИСТЕМА ЦЕННОСТЕЙ ВОЕННОГО СОЦИУМА США В ЗЕРКАЛЕ ПРОФЕССИОНАЛЬНОГО ПОДЬЯЗЫКА
}

\section{THE U.S. MILITARY COMMUNITY AXIOLOGY REFLECTED BY PROFESSIONAL SUBLANGUAGE}

\section{K. Agaphonova}

Summary: This article explores the system of values of the U.S. military subculture. It focuses on American service members' axiology, reflected in lexical and phraseological units of the military sublanguage informal register. The author puts forth and substantiates a thesis that the military lingo mirrors cultural and historical heritage, as well as the military subculture axiology. This study is exemplified in English and addresses linguists, interpreters, lecturers and a broad audience.

Keywords: national (ethnic) community, U.S. Armed Forces, military subculture, service member, military sublanguage, social-group dialect.
Агафонова Ксения Юрьевна

Преподаватель, ФГКВОУ ВО «Военный университет» Минобороны России

bc@mail.ru

Аннотация: Статья посвящена анализу системы профессиональных ценностных ориентаций армейской субкультуры США. Исследуется аксиосфера американского военнослужащего, явленная в лексико-фразеологических единицах неформального регистра подъязыка военной службы. Выдвигается и подкрепляется языковым материалом тезис 0 том, что военный субъязык отражает культурно-историческое наследие и аксиосферу армейской субкультурной среды. Исследование проведено на материале английского языка и адресовано лингвистам, переводчикам, преподавателям и широкой аудитории.

Ключевые слова: национальная (этническая) общность, вооруженные силы США, армейская субкультура, военнослужащий, военный подъязык, социолект.

функцией обеспечения защиты от нападения извне. Названная функция имманентна даже в случае нанесения превентивных ударов по вероятному противнику за пределами собственных границ [1, с. 23]. Подвижность армейской части социума связана главным образом с непрерывным изменением геополитического ландшафта, возникновением новых вызовов, поступательным развитием научной мысли, модернизацией образцов вооружения и военной техники и другими факторами.

Под военным социумом А.С. Романов понимает «устойчивое социальное образование, характеризуемое единством правовых основ регламентации профессиональной деятельности, общественно значимых социальных функций, культурно-исторического наследия, менталитета, идиома и аксиологических ориентаций, условий жизненного уклада» [5, с. 138]. Социальный институт вооруженных сил - культурный ответ общества на потребность в обеспечении национального суверенитета, безопасности и реализации интересов государства на международной арене. Военный социум США, как и всякого другого государственного образования, многолик. Он вбирает себя военнослужащих регулярных войск, национальной гвардии, резервистов, военных в отставке, служащих вооруженных сил, членов семей перечисленных и иных категорий граждан [Там же, с. 138]. Системообразующим компонентом армейской части общества выступает военная субкультура, представленная действующими военнослужащими. Армейская субкультурная среда, по А.С. Романову, «пропитана духом андроцентризма, имеющего глубокие исторические и тра- 
диционные корни. Андроцентризм мыслится как взгляд на мир с позиции мужских нормативных представлений и социальных моделей поведения» [3, с. 53-54]. Под гегемонией маскулинности, полагает Р.У. Коннелл, понимается примат мужских черт, практик, идентичностей. В воинской культуре гегемония маскулинности базируется на жертвенности, агрессивности, «жесткости», психоэмоциональной устойчивости, самодостаточности [12]. В подкрепление сказанного приведем такие устойчивые обороты неформальной коммуникации американских военных, как to talk the talk and walk the walk - 'отвечать за свои слова', complacency kills - 'держать нос по ветру, никогда не терять бдительности' (Әосл. самоуверенность приводит к гибели), to be as hard as nails / been there, done that - 'пройти огонь, воду и медные трубы', blood and guts - 'мужество, отвага, готовность к самопожертвованию', to bite the bullet - 'стоически переносить испытания, лишения, физическую боль' и др. [4, с. 37], [10]. В пользу андроцентричности профессиональной картины мира американского военнослужащего свидетельствуют такие словосочетания, как to man a ship / a unit -'укомплектовывать личным составом / экипажем судно или часть / подразделение', manned vehicle - 'пилотируемое транспортное средство', man at the wheel-'рулевой', man-borne radar - 'портативная РЛС', man by man - 'по одному, поочередно', man-controlled - 'управляемый', man-portable -'переносной' и др. [7, с. 190].

Как известно, совокупность сведений об окружающей действительности находит выражение в двух информационных потоках: синхроническом и диахроническом. Межпоколенная связь военного социума находит свое отражение в эстафете социально значимого опыта. Сохранение связей с прошлым преследует ряд целей. Во-первых, церемонии и традиции подчеркивают самобытность военной субкультуры. Во-вторых, почтительное отношение к памяти и ратным подвигам предшествующих поколений военнослужащих способствует (а) военно-патриотическому воспитанию зрелой личности воина, (б) формированию коллективной идентичности, (в) социальной когезии. Под последней понимается социально-психологическая связь членов воинского коллектива. Ср.. например, такие речевые обороты, как we leave no man behind - 'мы своих не бросаем', shoulder to shoulder - 'плечом к плечу', as one man / all to the last man - 'один за всех и все за одного'. В семантике приводимых фразеологизмов, отмечают А.С. Романов и Е.В. Лупанова, отчетливо прослеживается идея «исключительности воинского братства как социально-профессиональной общности, пронизанной духом коллективизма» [4, с. 37]. И, наконец, в-третьих, накопленный социальный опыт имеет потенциальное применение в будущем.

Аксиосфера военного человека зиждется на морально-этических ориентирах, обеспечивающих выполнение поставленной задачи и выживаемость в условиях боевых действий. Так, например, в основе морально-этической концепции The Army Values отражены следующие незыблемые ценности «униформированного мира»: Loyalty 'верность', Duty - 'долг', Respect - 'уважение', Selfless Service - 'беззаветная служба', Honour - 'честь', Integrity - 'добросовестность / честность', Personal Courage - 'личное мужество'. В своей совокупности перечисленные слагаемые профессионального этоса составляют акроним LDRSHIP = leadership - лидерство [14]. Основными функциями социального института вооруженных сил, осмысленного в понятиях фамилизма, значатся (а) воспроизводство новых поколений военнослужащих, (б) обеспечение вторичной социализация личности, (в) формирование профессионально актуальных знаний, умений и навыков, (г) поддержание «родственных» связей в воинском коллективе. Мы в полной мере разделяем точку зрения А.С. Романова и И.В. Балканова о том, что «в иерархии семейных ценностей, перенесенных на военный социум, главенствующая роль отведена надлежащему исполнению воинского долга, воспитанию чувства коллективной ответственности за будущее нации, обеспечению непрерывности межпоколенной эстафеты преемственности и воспроизводства аксиологических ориентаций воинской касты» [7, с. 101-102].

Как и всякая самостоятельная часть общества, полагает Б.Л. Бойко, армия отличается собственной профессиональной культурой. «Военнослужащим присущ особый modus vivendi, который реализуется на относительно изолированной территории воинских частей и командных инстанций» [1, с. 23]. С одной стороны, отношения в воинской среде регламентированы положениями общевойсковых уставов и руководящих документов. С другой стороны, система внутригрупповых отношений подчинена неписаным правилам этикета. Неотъемлемым атрибутом «униформированного мира» выступает признак-критерий знаковости (символизма). Последний, отмечает ученый, проявляется «как в форме эмблем на предметах, так и в форме эмблем - единиц языка» [2, с. 51]. Военный подъязык - особый языковой код, обслуживающий коммуникативные потребности армейского сегмента социума.

Военная субкультура воплощена нетольков вставных, формализованных и имеющих правовое обоснование отношениях. Специфика социально-профессиональной среды военнослужащих в полной мере раскрывается в повседневно-бытовом обиходе, неформальных правилах поведения, запретах и предписаниях. На примере лексико-фразеологических единиц военного субъязыка подкрепим изложенную мысль. Языковой материал извлекается методом сплошной выборки. Источниковой базой послужил специализированный словарь военного жаргона П. Диксона War Slang: America fighting words and phrases since the Civil War (2003). Рассматриваемый период - глобальная кампания США по борьбе с между- 
народным терроризмом (Post 9/11 Word and the Iraq War).

Высокий уровень профессионализма, наличие боевого опыта, гибкое и нестандартное мышление, мужество и выносливость, способность действовать как в составе подразделения, так и автономно - неизменные атрибуты эталонного воина. Ср., например, такие жаргонизмы, как field expediency - 'обходиться подручными средствами', fieldcraft - 'искусство ведения боя в полевых условиях' [11, р. 378], to be at the tip of the spear - 'находиться на острие', beans, bullets and band-aids - 'предметы первой необходимости в бою' (досл. бобы, боеприпасы и пластыри) [lbid., p. 373].

К категории очевидных антиценностей военной службы отнесены леность, нерешительность, профессиональная некомпетентность. Аксиологические ориентиры и поведенческие антиобразцы находят выражение в языковых подлинниках профессионального жаргона. Cр., например, road soldier - 'бездельник, лодырь' [lbid., p. 387], Sham Foo Master - 'военнослужащий, мастерски изображающий видимость бурной деятельности' [lbid., p. 388], oxygen thief - 'абсолютно бесполезный человек' (приводимое изречение соотносится с выражениями коптить воздух и бить баклуши) [lbid., р. 386], maggot - 'беспомощный, неопытный военнослужащий' (досл. личинка насекомого) [lbid., p. 383], flopper - 'не оправдавший доверия человек' (от flop - жарг. неудача, провал, фиаско; досл. - шлепок) [lbid., p. 378]. Отсутствие надлежащей подготовки, боевой выучки и опыта подлежат осуждению, о чем свидетельствуют жаргонизмы flying desk - 'канцелярский, офисный работник', penguin - 'не имеющий налета авиатор' [lbid.: 378], trained killer / keybord jockey - 'специалист в сфере компьютерных технологий, «айтишник»' [lbid.: 390], man behind the man behind the gun - 'тыловой вояка', shake and bake / greeny - 'новоиспеченный, неопытный, необученный военнослужащий' [lbid.: 389].
Эффективность военных организаций зиждется на жертвенности, воинском долге, альтруизме, добровольном и нередко иррациональном подчинении личности интересам и потребностям коллектива. Как отмечает П.М. Шилдс, «во исполнение приказа, военные либо убивают, либо прилагают усилия, направленные на поддержание работоспособности военной машины <...>. Жертвенность и субординация - фундаментальные для понимания военных организаций понятия». Сказанное в полной мере объясняет, почему индивидуализм или избыточный эгоизм могут представлять наиболее серьезную угрозу именно для армейской среды (Shields, 1993). Семы жертвенности воинского служения ярко прослеживаются на примере следующих устойчивых речевых формул профессиональной среды, - армейских клише. Train hard, fight easy and win or train easy, fight hard and die 'тяжело в учении, легко в бою', fight to the bitter end - 'сражаться до победного конца', to die with one's boots on - 'погибнуть при исполнении воинского долга', keеp your head on a swivel - 'держи ухо востро, будь всегда начеку', loose lips sink ships - 'болтать - врагу помогать', to hit the glory road / to die in the blaze of glory - 'пасть смертью храбрых'. Боевая закалка, отмечают А.С. Романов и Е.В. Лупанова, выступает одним из критериев профессиональной зрелости служивого человека. Разделенный опыт участия в боевых действиях «способствует формированию подлинно братских, в высшей степени доверительных отношений между военнослужащими» [4, с. 36].

В характерных феноменах языка военной службы отражены ментальность, идеалы, морально-нравственные ориентации профессиональной среды. Лингвокультурологический анализ самобытных феноменов языкового субстандарта позволяет проникнуть в мир ценностей военного социума, раскрывает особенности «речевого паспорта» представителя армейской субкультуры.

\section{ЛИТЕРАТУРА}

1. Бойко Б.Л. Вербальные и невербальные ритуалы как ценности профессиональной культуры военных // Организационная психолингвистика. М., 2019. №1 (5). С. 21-33.

2. Бойко Б.Л. Основы теории социально-групповых диалектов: монография. М.: Воен. ун-т, 2008. 184 с.

3. Романов А.С. Стереотипизация субкультурных констант в аксиологиии социально-группового диалекта (на материале ценностей и реалий военной службы в языковой культуре (ША): дис. ... уч. ст. доктора филол. наук. Шифр научной специальности: 10.02.19. М.: Воен. ун-т, 2020. 444 с.

4. Романов А.С., Лупанова Е.В. Дихотомические диады фразеологических единиц как средство выражения ключевых ценностей армейской субкультуры // Филологические науки в МГИМ0: Журнал. № 1 (21) 2020 / Гл. ред. В.А. Иовенко. М.: МГИМО-Университет, 2020. С. 34-40.

5. Романов А.С. Система аксиологических координат Gl в отражении девизов родов войск и видов вооруженных сил США // Вопросы психолингвистики. М., 2019. № 2(40). C.135-150.

6. Романов А.С., Шнякина К.В. Имя прецедентное как самобытный лингвокультурный артефакт речевого репертуара GI (на материале английского языка) // Современная наука: актуальные проблемы теории и практики. Серия «Гуманитарные науки», -2019. -№ 5-2. -С. 182-187.

7. Романов А.С., Балканов И.В. Вооруженные силы США в стереотипах американской периодики на примере метафорической модели “U.S. Armed Forces is Family" / А.С. Романов, И.В. Балканов // Современная наука: актуальные проблемы теории и практики. Серия «Гуманитарные науки», - 2019. -№ 7-2. С. 100-105. 
8. Романов, А.С. Этнические стереотипы армейской субкультурной среды США в знаках языка и культуры: монография. М.: Воен. ун-т, 2017. 231 с.

9. Судзиловский Г.А. Сленг - что это такое? Английская просторечная военная лексика. М.: Воениздат, 1973. 182 с.

10. Ammer C. The Facts On File dictionary of clichés. 2nd ed. N.Y.: Infobase Publishing, 2006. 534 p.

11. Dickson P. War Slang: America fighting words and phrases since the Civil War / P. Dickson. 2nd ed. Dulles, Virginia: Brassey's Inc, 2003. 428 p.

12. Connell R. W. Masculinities. Cambridge, MA: Polity Press, 1995.

13. Shields P.M. “A New Paradigm for Military Policy: Socioeconomics"// Armed Forces and Society, 1993. Is. 19. P. 511-531.

14. The Army Values. Available at: https://www.ausa.org/army-values (accessed 12 March 2020).

๑ Агафонова Ксения Юрьевна (bc@mail.ru).

Журнал «Современная наука: актуальные проблемы теории и практики»

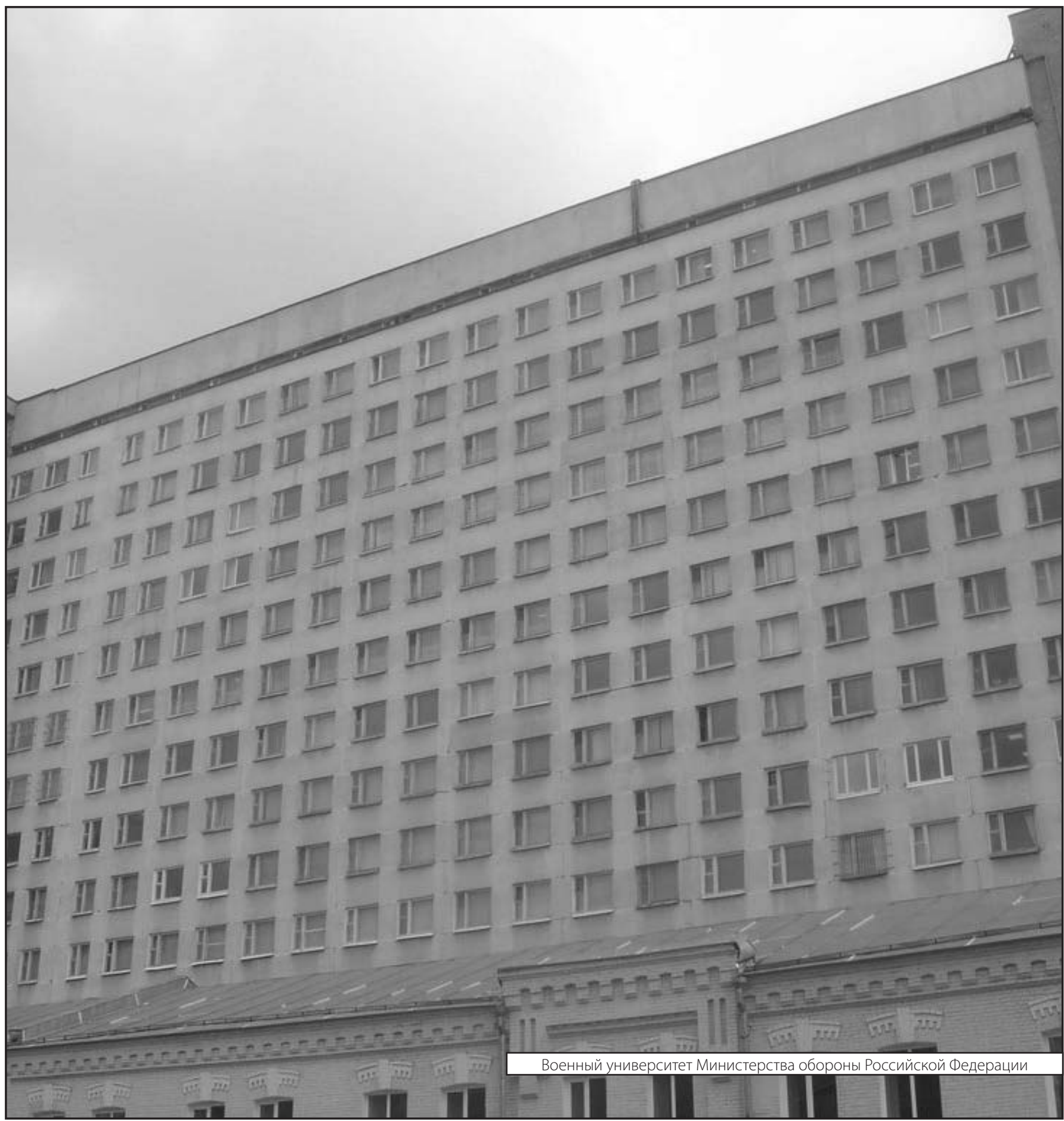

